\title{
MÍDIA, IDEOLOGIA E FINANCEIRIZAÇÃO
}

\section{MEDIA, IDEOLOGY AND FINANCIALIZATION}

DOI: http://dx.doi.org/10.15448/2178-3748.2015.1.18591

Muniz Sodré

Professor Emérito da Escola de Comunicação - UFRJ

\begin{abstract}
RESUMO: O presente artigo é a transcrição da conferência proferida pelo Prof. Muniz Sodré em 15 de agosto de 2013, na Pontifícia Universidade Católica do Rio Grande do Sul. Tratou-se da conferência de encerramento do II Seminário História e Ideologia: mídia, dominação e resistência. Nela, Muniz Sodré abordou o impacto do atual contexto de financeirização do capitalismo sobre a mídia, com ênfase para as implicações ideológicas, culturais e sociais das transformações contemporâneas dos meios de comunicação.
\end{abstract}

PALAVRAS-CHAVE: Cultura. Ideologia. Mídia.

ABSTRACT: This article is the transcript of a lecture given by Prof. Muniz Sodré on August 15, 2013, in Pontifícia Universidade Católica do Rio Grande do Sul. It was the closing conference of the II Seminário História e Ideologia: mídia, dominação e resistência. In it, Muniz Sodré discussed the impact of the current context of financialization of capitalism on the media, with emphasis on the ideological, cultural and social implications of contemporary transformations of the media.

KEYWORDS: Culture. Ideology. Media.

Boa tarde e muito obrigado pelo convite e pela presença. Para falar de comunicação, ideologia e resistência, eu escolhi tomar a questão da cidadania como um vetor ideológico da mídia. Toda vez que nós associamos mídia a cidadania - e essa associação é ideológica - a atitude imediata é, quase sempre, a de se pensar na mídia como se fosse uma parceira natural dos direitos sociais - com direitos sociais eu quero dizer educação, saúde, habitação, proteção coletiva ou segurança pública - que, na sociedade moderna, são posteriores aos direitos civis. Os direitos sociais aparecem depois dos direitos civis, que são a representação democrática, a liberdade de expressão etc. Então, quando a mídia surge com a força que surge, o pensamento geral - digamos, de Estado, de público e de eventuais grupos de controle de pensamento da mídia - é de associar os direitos sociais. Quer dizer, associar educação, saúde a bens públicos, pensados coletivamente. Mas se nós nos restringirmos ao caso brasileiro, o foco gerativo desses direitos sociais é certamente a Constituição Federal de 1988. Porque a Constituição de 1988 transferiu os direitos sociais da ordem econômica, como estava na constituição anterior,

\footnotetext{
* Transcrição da conferência de encerramento do II Seminário História e Ideologia: mídia, dominação e resistência, proferida pelo prof. Prof. Muniz Sodré em 15 de agosto de 2013, na Pontifícia Universidade Católica do Rio Grande do Sul (transcr. Jaime Valim Mansan).
}

Oficina do Historiador, Porto Alegre, EDIPUCRS, v. 8, n. 1, jan./jun. 2015, p. 134-157. 
para a ordem social, e reinterpretou esses direitos como direitos universais de cidadania. Portanto, o conceito de cidadania se amplia com a Constituição de 1988, e se amplia como apropriação social de bens coletivos. É assim que eu gostaria de caracterizar cidadania aqui, hoje. Cidadania como a apropriação social de bens coletivos.

Mas uma coisa é o formalismo dos direitos. Outra é o exercício efetivo desses direitos. Realmente, no contexto político e econômico em que esses direitos sociais se institucionalizaram - quer dizer, no contexto da Constituição de 1988 - a mídia já era parceira irreversível de outra coisa. A mídia já era parceira irreversível do capital financeiro. Já era parceira irreversível do mercado. E do Estado, empenhado em políticas de ajuste fiscal, típicas do modelo neoliberal. Ora, essa dissonância, esse desacordo não é normalmente apontado pelos estudiosos, pelos analistas de Comunicação. Porque, na prática, isso implica uma dissonância ideológica entre o ativismo em prol da universalização dos direitos sociais e a valorização, que a mídia faz, da lógica do mercado. Essa lógica do mercado é afim à privatização na apropriação dos bens coletivos que estão implicados nos direitos sociais. Aqui há, portanto, o que eu chamaria de uma dissonância ideológica: de um lado, as instituições civis caminham em um sentido, enquanto a mídia caminha sempre no sentido do mercado e do capital financeiro.

A consciência individualista se sobrepõe no espaço público à consciência solidária, gerando condições desfavoráveis à quaisquer novas estratégias de institucionalização dos direitos sociais. Portanto, a cidadania serve de referência para essa nova qualificação histórica da existência, que eu chamo de bios midiático, conceito que está em alguns livros meus, como Antropológica do Espelho (2002), As Estratégias Sensíveis (2006) etc. O bios midiático como uma nova orientação existencial, uma nova forma de vida que conjuga tecnologia e mercado. Esse bios midiático, essa nova qualificação histórica da existência, é basicamente a cidadania consumidora, cidadania definida a partir do consumo. Então o social passa a ser qualificado pela capacidade de consumo, e é isso o que passa a definir a agenda pública. Sociabilizar-se é consumir.

Nós podemos assinalar, nesse ponto, uma transformação na organização tradicional da sociabilidade republicana. O comum republicano se investe, do ponto de vista do Estadonação, das formas de ordenamento jurídico e das fronteiras territoriais. Isso é o comum estabelecido pela república. Mas na regulação da sociedade civil, se investe da forma de esfera pública. Nós entendemos esfera pública como espaço de comunicação em que cada indivíduo passa do discurso dual - do diálogo, a dois - à relação discursiva com a massa

Oficina do Historiador, Porto Alegre, EDIPUCRS, v. 8, n. 1, jan./jun. 2015, p. 134-157. 
anônima. Portanto, esfera pública como espaço cultural. A moderna ideia de cultura como um campo autônomo de sentido seria uma espécie de resposta epistêmica à fragmentação da unidade mítica tradicional, de propriedade politicamente comum. A cultura - o termo cultura e a ideia de cultura - aparecem no Ocidente quando a ideia de Deus, como um organizador geral, começa a declinar. É quando a Igreja vai perdendo progressivamente seu estatuto hegemônico - portanto, a ideia do sagrado, do transcendente, como interpelador da consciência individual - que a cultura aparece como essa síntese de sentido. Assim, a cultura como campo autônomo de sentido é uma resposta à fragmentação da unidade mítica, da unidade teológica, da unidade divina tradicional. Tanto que cultura e religião, cultura e catolicismo, são conceitos estreitamente ligados. Basta ler aquele livro de T. S. Eliot (2013) sobre o conceito de cultura, onde ele destrincha isso dessa maneira.

A política e a cultura presidiram a reinterpretação da koiné antiga, da comunidade antiga, na Europa no século XVIII. Fragmentando-se a unidade mítica, divina, a política e a cultura aparecem para reinterpretar a unidade. A irrupção dessa realidade nova na História foi um dos efeitos da transformação das relações de produção - a Revolução Industrial - que se alinhava com a expansão da democracia burguesa. Na esteira das proclamações teóricas e políticas de Rousseau, eram estratégicas a educação e a cultura como instrumentos de concepção da democracia, como valor e como fim. Democracia não mais apenas como mecanismo de governo, mas democracia como valor, como fim social. Para isso, precisava educação e cultura.

A disseminação dos dogmas de soberania do povo demandava o trânsito livre de ideias, a liberdade de expressão, que era uma exigência histórica da soberania popular. As ideias tinham que transitar. As informações tinham que passar. Cultura e política eram estreitamente ligadas, estreitamente vinculadas.

O espaço público se fortalece na Europa ao longo dos séculos XVIII e XIX como lugar de manifestação da vontade geral, não de vontades particulares. Então, o espaço público - isso é fundamental para entender a mudança da mídia hoje - passou pelo que sempre foi político e cultural. Sempre foi uma conjugação de política e de letras, na acepção ampla e não apenas literária da palavra: letras como literatura, ficção, poesia, mas também como discurso, publicismo, debate. Isso sempre esteve junto com a política. Então, do ponto de vista do discurso, o espaço público se apoiava em instituições literárias mas também na arena de debate, em meios editoriais, além da imprensa, que era vista, pelos pragmatistas - como Dewey, por exemplo - como um agente promotor da cultura.

Oficina do Historiador, Porto Alegre, EDIPUCRS, v. 8, n. 1, jan./jun. 2015, p. 134-157. 
A associação entre o parlamento e as letras era realmente familiar aos intelectuais oitocentistas. Não havia como separar um do outro. Eu estou falando da Europa, mas também não havia como separar, aqui no Brasil, em momentos de afirmação da nacionalidade e da modernização do país. Um deles, por exemplo, foi o abolicionismo. É impossível pensar o abolicionismo sem o papel da imprensa, mas também dos comícios e clubes de discussão letras - e vejam como eram sólidos os intelectuais do abolicionismo, negros e brancos. Então, para a instância política, isso era muito importante, senão essencial, como Dewey sustentava. Dewey dizia: "o aperfeiçoamento dos métodos e de condições de debate, de discussão, de persuasão: este é o problema do público". Ou seja, para esse aperfeiçoamento, precisava-se de uma retórica particular, uma retórica condicionada a uma cultura específica, algo como a boa retórica platônica e aristotélica. Por exemplo: como se sabe, Sócrates, via Platão, empreende uma luta contra os sofistas, os mestres da retórica. Platão deixa bem claro que o problema não é contra a retórica inespecificamente: é contra a má retórica. Existia a boa retórica e a má retórica. A boa retórica era a dialética. Então, não é possível a comunicação e o trânsito de ideias sem uma forma retórica, discursiva, expressiva, capaz de fazer a pessoa compreender.

A retórica, portanto, era e sempre foi necessária para expressar a linguagem das massas no espaço público. Quando a razão é pura - por mais lógica que ela seja, por mais racional que ela seja - é mais um instrumento de dominação. A desconfiança que grandes agitadores de massas têm da razão em si mesma vão no empuxo dessa argumentação. É conhecida a frase de Lutero, grande reformador, sobre a razão. Ele disse: "Die Vernunft, diesem Hure" - 'a razão, essa prostituta'. Eu disse 'prostituta' porque fica melhor, Hure em alemão é a forma abreviada... Chamou a razão disso. Porque, sem uma retórica capaz de expressar a linguagem das massas, ela é só um instrumento de dominação, como outros.

Por trás dessa retórica, se achava o sistema educacional. A retórica voltada em si mesma, como pura técnica discursiva, como uma técnica desencarnada da criatividade cultural, da política e, portanto, desencarnada do ativismo cívico, não é nada. Tem que ter por trás o ativismo cívico, educação-cidadania. Mas essa retórica já existia, sempre existiu, e ela era o embrião das indústrias de difusão culturalista junto ao grande público. Por isso ela foi objeto de autores como Tocqueville, Proudhon, Baudelaire, desde meados do século XIX, desconfiando disso, dessa retória que estava a troco só da sedução.

Na primeira metade do século XX, essa retórica industrializada se tornou objeto novo de análise graças à noção de indústria cultural, expressão cunhada, como todo mundo sabe, por Adorno. Não é dele. Se vocês lerem esse grande - e divertido - romance de Flaubert, que

Oficina do Historiador, Porto Alegre, EDIPUCRS, v. 8, n. 1, jan./jun. 2015, p. 134-157. 
é Bouvard et Pécuchet - que tem uma bela tradução em português, acho que até é de tradutor gaúcho, é muito fácil de encontrar - vocês encontram em Bouvard et Pécuchet a expressão “cultura industrial". Adorno só inverteu: "indústria cultural”. O que em Bouvard et Pécuchet é chamado de cultura industrial é a mesma coisa: são os folhetins, a imprensa... Essa expressão foi teoricamente reforçada pelo conceito de reprodutibilidade, de Walter Benjamin. O diagnóstico de homogeneização cultural se configura como um ponto de convergência para toda essa linhagem de crítica cultural que a Escola de Frankfurt representou muito bem.

Mais tarde, essa expressão "indústria cultural” se estendeu à mídia eletrônica, devido à importância crescente do rádio e da televisão, perdeu força com a tecnologia do digital ninguém fala muito hoje em indústria cultural - e foi progressivamente substituída pela expressão "indústria de conteúdos”, que se fala muito. Fornecer conteúdos, indústria de conteúdos. No bojo de transição do paradigma industrial - que se caracteriza pela tecnologia dos motores - para o paradigma informacional - que é a tecnologia eletrônica - o espaço público se ampliou tecnologicamente. O espaço público é enorme, imenso. Ele passou a ser absorvido pelas indústrias de conteúdos culturais, mas com uma conexão apenas remota com o sistema educacional. Nesse crescimento da indústria cultural, transformando-se em indústria de conteúdos, a educação 'dançou'. A educação é uma estrela no céu, e às vezes uma estrela cadente.

Entre os anos 1960 e os anos 1990, o espaço público parecia ter encontrado no broadcast televisivo, parecia ter encontrado na televisão em circuito aberto, ou na informação em circuito aberto, seu ícone principal. Quer dizer, entre 1960 e 1990, a televisão foi o ícone do espaço público. Por quê? Pela grande capacidade que a televisão sempre teve - e ainda tem - de transpor as velhas barreiras sociais, as barreiras de classe, de credo, de sexo, de idade. E assim a televisão foi constituindo audiências diversificadas, e se impôs essa televisão como um medium prototípico do alcance massivo.

Aí começaram a se levantar hipóteses críticas sobre o potencial de concorrência, em termos educacionais, com a família e com a escola. Entre os anos 1970 e 1990, o número de artigos publicados no mundo ocidental sobre esse tópico - o mal que a televisão faria às crianças, concorrendo com a família, com os pais, com a escola - é inacreditavelmente grande. É muito, muito grande. Então, na década final do século passado, a tecnologia digital passou a impulsionar, passou a consolidar a fragmentação dos públicos da mídia eletrônica tradicional sob a forma de individualidades comunicantes, ou indivualidades interativas. $\mathrm{Na}$ televisão, arguir é falar com interação. A interação era regida pelo modelo de uma massa

Oficina do Historiador, Porto Alegre, EDIPUCRS, v. 8, n. 1, jan./jun. 2015, p. 134-157. 
anônima, uma massa heterogênea. Esse modelo, que vigia sobre a televisão, dá lugar à interatividade, palavra de vinte anos para cá. Interatividade é uma palavra muito nova. Implica o quê, a interatividade? Um processo gradativo de apropriação da tecnologia da comunicação pelos usuários. Portanto, a comunicação deixando de ser unidirecional, deixando de ir de um centro emissor para a massa anônima, para a heterogeneidade, e os usuários - essa heterogeneidade - se apropriando da tecnologia. A Internet é isso. A Internet é o medium, a mídia que sintetiza todas as possibilidades da mídia anterior. Sintetiza a imprensa escrita, rádio e televisão. A qualidade dessa síntese é outra coisa a ser discutida. Ela sintetiza tecnicamente, como possibilidade. A Internet também acena para novas modalidades de trabalho intelectual, afinado com o desenvolvimento da rede mundial de computadores. $\mathrm{O}$ broadcast, a televisão em circuito aberto, é progressivamente substituído pelo pointcast, que é a transformação da audiência comum em pontos de mira individualizados, que são capazes de fragmentar, de provocar a fragmentação do espaço público que tinha sido midiaticamente ampliado. A mídia ampliou o espaço público mas, nessa ampliação, despolitizou e deseducacionalizou o espaço público. Tecnologicamente é amplo, é enorme.

Essa substituição de broadcast por pointcast - mídia tradicional ou, como eu chamo, "mídia jurássica" - pela nova mídia - que é a mídia eletrônica, a Internet, as redes sociais essa substituição opera no âmbito da atual financeirização do mundo. Nós estamos em um momento em que, mesmo com os recuos do neoliberalismo e das finanças, o mundo hoje é financeiro. O poder do capitalismo é o poder das finanças. A mídia opera essa substituição no âmbito dessa financeirização. Mas isso não afeta radicalmente a homogeneização cultural que já tinha sido denunciada, ideologicamente denunciada, pela Escola de Frankfurt. Por quê? Há um aporte de natureza econômica. Eu vou explicar por que a homogeneização é fundamental a essa lógica, a essa retórica da mídia, seja ela qual for.

Considere-se um produto financeiro. O que é um produto financeiro? Moeda, título, crédito... Esses produtos financeiros são perfeitamente homogêneos. Por quê? Porque os agentes das finanças não se interessam por nenhuma outra característica do produto a não ser o preço. Quem se interessa pelas outras características é o comprador e o produtor. Mas o agente financeiro não. Ele se interessa pelo preço. No mercado monetário, por exemplo, você empresta um real. Um real emprestado durante um dia é equivalente a qualquer outro real emprestado durante um dia. Não há diferença entre um real e outro. Não há diferença entre um dólar e outro, entre um euro e outro. Ou seja, nenhum banco pode praticar uma taxa de juros superior às taxas de mercado sob o pretexto de que os reais dele são melhores do que os

Oficina do Historiador, Porto Alegre, EDIPUCRS, v. 8, n. 1, jan./jun. 2015, p. 134-157. 
reais de outro banco, são de melhor qualidade do que os oferecidos por outro banco. Isso parece evidente, uma obviedade. Mas, quando você olha do lado dos mercados nãofinanceiros, a homogeneidade do produto desaparece quase sempre. Quando você olha o lado do mercado produtivista, ele vê se o produto serve ao comprador, por exemplo, pegando a roupa e esticando-a para ver se é boa, ver se dura, se é bonita, se a marca é boa. Não há homogeneidade aí. Nesse caso nota-se uma heterogeneidade de gostos, de escolhas, de seleção. No mercado financeiro, a homogeneidade é a regra.

Essa explicação está valendo aqui como índice da hegemonia da informação veloz, por efeito da tecnologia eletrônica. Porque, sob aqueles velhos pruridos da heterogeneidade cultural, da heterogeneidade simbólica, no âmbito da cultura, o que importa mesmo, agora, no mundo regido pelos mercados de capitais, é que a informação circule bem e velozmente. Não importa que informação é essa. Importa que ela circule bem e velozmente. Porque todas as ofertas, todas as demandas de um mesmo produto, homogêneo, podem ser confrontadas praticamente em permanência no mesmo lugar. Por exemplo, pode ser a bolsa, se for produto financeiro. Como é a rede de telecomunicações. O mercado monetário e o mercado das trocas linguísticas ou informativas tem uma homologia, uma isonomia e uma isomorfia.

É nesse âmbito que aquela velha expressão, que circulava muito no início da Escola de Comunicação e nos EUA, chamada "comunicação de massas", é uma expressão equivocada. É na verdade um resultado equivocado da confusão entre comunicação e transmissão. Porque o que efetivamente essa expressão designa é a informação - com informação eu quero dizer atualidade, entretenimento, difusão de conteúdos culturais - disseminada pela mídia. É isso que interessa. Portanto, é esse espírito, digamos, distributivista... Isso, vejam só, não é tão novo assim: já nos anos 1920, esse grande educador e filósofo, John Dewey - esse honra os EUA - ele diz isso (eu disse isso hoje à tarde, lá no programa do Juremir, falando com o pessoal da Mídia Ninja). Ele disse o seguinte: que ele achava que os jornais deveriam deixar de ficar reportando coisas objetivamente, que é a chamada informação, a notícia, e aí o jornal reporta. Ele disse que isso, em um determinado momento, cansa. Ele diz "we will be fed up", fatigados dessa reportagem infinita de acontecimentos, e que o próprio jornalismo inculca ideologicamente no seu público como se fosse o alimento de cada dia, como se fosse algo sabido e necessário. Ele diz: se deveria, talvez, passar desse ponto de apenas reportar para ser um instrumento de conexão, no espaço público, com vistas à educação e à alta educação, para um mundo que está se abrindo. E essa oportunidade está acontecendo agora, com a Internet. Eu não creio que o jornalismo se defina hoje por conteúdo de qualidade. Eu sou um pouco 
antigo... O que está importando neste momento é conexão. O êxito que os meninos da Mídia Ninja e outros estão tendo nas ruas irão me dar novos ângulos, eles me disseram. Eu disse a eles que ninguém está se lixando para esses novos ângulos. O sujeito está no êxtase da conexão. Não há nada mais extático, não há nada que dê mais extâse, não há nada que dê mais gozo pessoal do que conexão. O estar juntos, o conectar-se, fisicamente, corporalmente ou tecnologicamente: essa conexão é o que importa.

Mas há, nessa conexão, um espírito distributivista, ou um espírito circulatório, que afeta a velha cultura disseminada no espaço público. Quer dizer, o espaço público foi tecnologicamente ampliado, ao longo do século XX. Ampliou-se muito. Foi progressivamente se liberando daquela ideologia cívica que era característica do período oitocentista. Mesmo monopolizada pela burguesia ascendente, essa ideologia abrigava pretensões universalistas. Pretensões como liberté, égalité, fraternité, para que, no escopo heterogêneo das classes sociais, se pretendia mobilizar, se pretendia educar, com vistas ao espírito da burguesia. Hoje, o espaço público é uma esfera, não digo uma esfera cultural, mas uma esfera culturalizada. É diferente. Quer dizer, é uma esfera de outra coisa, como álibi da velha cultura. O que é uma esfera culturalizada? É uma fonte de entretenimento, de conteúdos fragmentários de conhecimento com a aparência de vida cultural, mas sem potência de referenciamento comum. Nunca podemos saber tanto quanto agora. É uma comodidade. Sempre estiveram aí as enciclopédias, mas puxar uma enciclopédia e ir atrás é mais difícil. Mas hoje, apertei no Google e eu sei imediatamente o que é. E vou buscando. Nunca o conhecimento fragmentário esteve tanto à minha disposição quanto agora. E o entretenimento e a diversão também. Com o álibi da cultura, o álibi da velha cultura. Isso é o que eu chamo culturalismo, a esfera culturalizada. Culturalismo é a redução ideológica da dinâmica da produção simbólica à distribuição de conteúdos significativos. Para quê? Para uma nova política? Não, para uma nova gestão social. Para uma nova administração do social. Porque, nessa nova ordem social, o que efetivamente toma o lugar da política é a gestão, é a administração. O que efetivamente importa é a administração e a gestão. Há pouco eu conversava sobre isso. Eu dirigia um órgão público, durante o governo Lula: a Biblioteca Nacional. Uma experiência pequena mas uma experiência dura. E eu me dei conta do seguinte: dinheiro não é o único problema do estado brasileiro. Nunca foi. O problema é gestão. O problema é administração. Administrar e gerir é muito difícil. A incompatibilidade da chamada modernidade não é de ordem tecnológica, é de ordem gerencial. É de ordem gestionária. Essa nova gestão do social é operada por corporações de mídia. Quer dizer, no limite, a soberania do mercado toma o lugar da

Oficina do Historiador, Porto Alegre, EDIPUCRS, v. 8, n. 1, jan./jun. 2015, p. 134-157. 
soberania política. Essa é uma operação ideológica da modernidade que estamos vivendo. A soberania do mercado converte a vida pública oitocentista à vida em público. É diferente. $\mathrm{O}$ que é a vida em público? É uma estetização de tudo, uma estetização de todos, aptos à visibilidade coletiva. É um poder de natureza estética com remotas intenções políticas. Nunca se estetizou e se visibilizou tanto a vida pessoal quanto agora. É verdade que isso estava até um tempo atrás no nível dos atores e atrizes. Atores com revistas, declarações loucas, eram entrevistados para mostrar sua casa, como vivem, quantos filhos têm, quantos namorados, quantos amantes... Depois, quebradas as barreiras, como se relacionam amorosamente, sexualmente... E neste momento, as redes sociais democratizam isso. Nunca se fala tanto de si mesmo como nas redes sociais. Por enquanto não se conta ainda a vida sexual, mas vai se contar, porque o passo é esse.

Ao olhar analítico, se configura uma nova realidade em que pontificam desde amplas frações de faixas etárias das classes médias até a juventude das periferias urbanas, que são aglutinadas por meio de redes alternativas de comunicação baseadas na Internet e que são socialmente extensivas, por meio de organizações de entretenimento, que são organizações lúdicas - shows musicais, jogos coletivos... - a quem quiser, a quem puder. $\mathrm{O}$ entretenimento - e não estou fazendo nenhum juízo moralista sobre o entretenimento - substituiu a ideia oitocentista de cultura. Essa ideia circula na academia, nas universidades, ou então junto a artistas do entretenimento, agentes do entretenimento, que se diferenciam de outros agentes do entretenimento dizendo 'olha, eu sou mais culto que vocês'. Aí você começa a estabelecer uma hierarquia de classes sociais do entretenimento. Então você vai dizer assim: olha, Chico Buarque, Caetano, Gil, Milton Nascimento, João Bosco - não estou criticando, inclusive alguns deles são amigos meus - não são iguais a... não vou dizer os nomes dos outros que seria ofensivo. É diferente. E você reconhece, a partir desses padrões, uma hierarquia cultural nos outros. Por exemplo, eu gosto de violão e nunca tinha ouvido falar, até pouco tempo atrás, em um compositor gaúcho. Eu nunca tinha ouvido falar o nome dele. E e mostraram uma música dele, com um tema aqui da gauderiada, dos gaúchos, que não é muito a minha praia. Eu fiquei fascinado. Eu disse: mas vem cá, esse cara aí tem a mesma voz do Caetano, mas ele canta melhor que o Caetano. E Caetano é meu amigo! Ele compõe bem... Como é que eu nunca ouvi? É uma beleza. E eu sei, logo, que ele é diferente da gauderiada. Chama-se Vitor Ramil. E sabem que ele é irmão daquela dupla, Kleiton e Kledir, que eu, lamento, não aprecio muito. Mas o Vitor Ramil, ótimo! Nota-se porque entra em um circuito de qualidade, por tais e tais características, que musicalmente a gente poderia dissecar agora, mas o cara é ótimo.

Oficina do Historiador, Porto Alegre, EDIPUCRS, v. 8, n. 1, jan./jun. 2015, p. 134-157. 
Muito bom, voz bonita, canta muito parecido com o Caetano, inclusive melhor que o Caetano. E Caetano canta muito bem.

Então, não se exercem mais da mesma forma os efeitos da grande mídia - jornais, revistas, televisão - sobre esse novo tipo de público. Não é mais o mesmo efeito. Ora, então um começo, digamos, razoável para se entender o escopo disso que eu estou chamando de culturalismo é observar a poltrona lie-flat da primeira classe no avião. Ou na executiva, em algumas companhias aéreas. E observar apenas, que eu não sentei nela não, porque é muito cara. O que elas oferecem ao passageiro, essas poltronas? Oferecem "I.C.E.": Informação, Comunicação e Entretenimento. É isso que ganha o cara em uma lie-flat. É a mesma coisa que, no âmbito da televisão, se chama de cultura. Oferece cultura ao passageiro: informação, entretenimento, variedades. Quer dizer, em última análise, o que se oferece como cultura é sempre um conteúdo vendável. O que se oferece, portanto, é sempre um negócio. Essa ideia de cultura, que eu chamo de culturalismo, se ajusta perfeitamente a um novo tipo de gestão do social, em que o controle público do sentido, a administração total toma o lugar da velha política. Portanto, se trata aí de cultura como uma instância de conformação do consenso, de cultura como hegemonia, hegemonia do sentido. Cultura é, aqui, a cena ideológica em que ganha sentido o exercício do poder de natureza gerencial. É essa cultura que estamos vivenciando. A cultura como gestão do social. A cultura como um lugar fortemente ideológico dessa gestão.

A televisão, portanto, ou qualquer outra modalidade de expressão audiovisual para grandes públicos, vinha liderando, há mais de meio século, essa cultura que é autorreferente, que é gestionária do social, por meio de imagens. Trata-se de uma combinação da linguagem do comércio, ou a linguagem do dinheiro, com a atmosfera emocional, quer dizer, o ethos, os costumes, da vida em sociedade. O poder que resulta daí, o poder dessa cultura - eu sustentei isso em um livro meu - é de natureza moral. O poder da televisão é um poder de natureza moral. Que moral é essa? É uma moralidade comerciante. É uma moralidade de modernização do consumo. Esse poder financeirista - sobre o qual não dá pra dissertar longamente aqui e que correspondeu em um determinado momento à doutrina neoliberal - não é como dizem muito os de extrema-esquerda da economia. O neoliberalismo não é anacrônico. $\mathrm{O}$ neoliberalismo é modernizador, tem aspectos fortemente modernizadores. É preciso rever a teoria do neoliberalismo, Hayek, esse grande economista, melhor que o Friedman, mas o neoliberalismo tem aspectos de modernização, está junto com o consumo. O capital é modernizador. Isso não quer dizer que ele nos resgate, nos salve nem nos console. Tem

Oficina do Historiador, Porto Alegre, EDIPUCRS, v. 8, n. 1, jan./jun. 2015, p. 134-157. 
aspectos modernizadores fortes: junto com o domínio, é modernizador. Então, é uma moral de modernização do consumo.

A televisão, portanto, é, no fundo, um eletrodoméstico - para usar a frase de Fellini, "a televisão é um eletrodoméstico" - financiado por vendedores de eletrodomésticos, desde as geladeiras até os aparelhos celulares, mas é um eletrodoméstico que funciona por imagens, e com um pedagogismo ideologicamente implícito. O que é esse pedagogismo, que nos inculca ideologicamente há sete décadas? A televisão, nesse espaço público de imagens, vem ensinando, a cada um de nós, o seguinte: cada um de nós deve administrar uma imagem própria. Essa imagem própria é uma atualização daquela velha persona, a máscara latina - em latim, persona é máscara - aquela máscara com a qual você constrói a personalidade, a individualidade. A personalidade já é a aposição da máscara. Quem é que mandava administrar psicologicamente a persona antes? Era a moral. Era a persona própria, ou então a dissolução das diferenças individuais na figura da pessoa jurídica. Agora, a gestão da persona de cada um é um imperativo das novas formas de relações sociais, das novas tecnologias da comunicação, como a Internet ou as redes sociais, onde cada um, dialogando, conversando, administra sua própria imagem, dá sua imagem. A realidade ou a verdade dessa imagem não importa muito. Cada máscara que usamos na rede - eu falo porque usamos máscara, usamos o tempo inteiro, fora da rede ou não, tem sempre a máscara, pode ser uma máscara moral - é um pouco como aquelas máscaras que, nos séculos XVI e XVII, em Veneza, a máscara veneziana que os homens e mulheres elegantes usavam, saíam mascarados para os bailes, encontros amorosos... Fazia parte da elegância de Veneza usar máscaras. A persona, portanto, a máscara de agora, é um imperativo dessas novas formas de relações sociais, dessas novas tecnologias de comunicação, como a Internet e as redes sociais. Fora desse ensinamento administre sua imagem - o que predomina na televisão é a reciclagem culturalista. A televisão é lixo cultural reciclado. Essa é a reciclagem culturalista.

Quando a linguagem do dinheiro está ausente de um sistema televisivo, sobra a dimensão da cultura. Por exemplo, a expressão "TV Cultura" de São Paulo, onde eu fui, três meses atrás, dar uma palestra, para a diretoria da TV Cultura. Por que é "TV Cultura"? É uma boa televisão e está sempre ameaçada. Um bom canal. Porque ela é forçosamente diferente da TV comercial. Porque a TV comercial recicla interminavelmente produtos já consagrados pelo mercado. Vocês não vêem as novelas da Globo? São muito bem feitas, realmente muito bem feitas, sedutoras. Mas é cultura reciclada. É como aquele jogo antigo, Quiz, em que você fica acertando: se bota uma novela dessas, o sujeito que for leitor velho vai dizer 'olha, isso

Oficina do Historiador, Porto Alegre, EDIPUCRS, v. 8, n. 1, jan./jun. 2015, p. 134-157. 
aqui está no livro tal, romance tal, tal...' e você compõe um pastiche bem feito daquilo, que dá outro resultado, mas é pastiche. É uma reciclagem. Muito bem feita, às vezes muito atraente, porque a produção é bonita, as atrizes em geral são bonitas - há as feias, mas também há as bonitas [risos da plateia] - então agrada o público.

A cultura que aspire à representação do valor público ainda guarda alguma coisa da antiga transcendência oitocentista, com um pano de fundo de um certo ativismo social por meio da cultura. Esse ativismo social por meio da cultura é o que está ocorrendo agora com os jovens ativistas. Quer dizer, a cultura é um meio de fazer ativismo porque a política já está podre. Esse é um problema da atualidade. Mas a cultura é um novo instrumento de dominação. Porque a dominação pelo mercado se faz pela cultura.

O problema, portanto, é que, apesar da sua real importância histórica como substituto ao determinismo do instinto natural - a cultura aparece para substituir o instinto natural -, a noção de cultura continua hoje, como no passado, ambígua e abstrata. Não se sabe muito bem o que quer dizer cultura quando se diz cultura: se tenta, mas não se sabe. Essa ambiguidade da noção permanece apesar das semelhanças que são evidentes ao longo da evolução da história ocidental. São semelhanças que persistem até hoje porque, de fato, a ideia de cultura como campo autônomo é um fenômeno moderno, da modernidade. A cultura tem sido uma forma alinhada a outras formas, como a democracia, por exemplo - moderna. A democracia dos direitos civis é moderna. A escola é uma forma moderna. A mercadoria é, cada vez mais, uma forma moderna. Marx nos mostra isso claramente: que tipo de forma é a mercadoria. São formas constitutivas da sociedade burguesa.

Mais precisamente, a cultura é a forma ideológica assumida pelo conhecimento assentado no comum burguês. É a forma ideológica do conhecimento. A singularidade dessa forma que é a cultura está em que ela não é alguma coisa que a percepção do sujeito apenas reconheça, porque a cultura não é uma forma comum: ela é uma trans-forma. Quer dizer, é uma forma que modifica a percepção. É uma forma que transforma a percepção, porque ela é vetor do espaço público. E espaço público não é puro espaço de comunicação, em que todo mundo fale. Isso é um grande engano. O espaço público não é um aglomerado de vozes, apenas, cada um gritando e dizendo sua verdade. Espaço público é aquele em que a voz de um pode ser transformada pela de outro. É um conversor. É como esses conversores com os quais você muda de $220 \mathrm{v}$ para $110 \mathrm{v}$ ou $110 \mathrm{v}$ para 220v. Para, no espaço público, a voz de um ser transformada pela voz de outro, é preciso um espaço político. Não é a voz em si mesma, não é a comunicação em si mesma.

Oficina do Historiador, Porto Alegre, EDIPUCRS, v. 8, n. 1, jan./jun. 2015, p. 134-157. 
Cultura, portanto, sendo uma forma ideológica, não é a mesma coisa que conhecimento. Isso é uma distinção que deveríamos ter na cabeça e estabelecer. Vamos imaginar o conhecimento como um mar em que se deva navegar. Cultura não é esse mar. A cultura é o mapa. É uma carta de navegação. Se o conhecimento é o mar, a cultura é o portulano, como diziam os navegadores antigos. É a carta de navegação. Então, antes mesmo que o conhecimento se imponha, a cultura já se faz presente, como uma matriz de orientação, para fazer diferenças, para estabelecer critérios, mas também como um mapa de memória do saber que é pertinente à reprodução da consciência burguesa. Só que é o conhecimento que impulsiona a universalização da cultura. A força do conhecimento. Essa matriz, ou esse conjunto de formas simbólicas, publicamente disponível, sempre pressupôs uma elite moral, ou uma elite ético-política de filiação burguesa. Sempre houve uma elite moral por trás da disseminação da cultura. Ou uma elite moral de natureza religiosa, ou uma elite moral de natureza efetivamente erudita, livresca. Por isso que eu disse antes que a cultura - e não falta quem sugira isso - pode ser uma resposta muito ambígua à fragmentação da experiência mítica tradicional, da experiência que era teologicamente orientada. A cultura como uma substituição da religião. As teorias da cultura, portanto, seriam coniventes com o desejo de restauração daquela unidade que se perdeu com a institucionalização da modernidade. Quer seja voltada ao passado, insistindo na comunidade, na tradição, no retorno às origens - isso caracterizou, por exemplo, o romantismo - quer seja voltada para o futuro, a cultura voltada para o futuro, que é o que caracteriza o projetualismo moderno, o projetualismo do progresso, que quer recompor a experiência perdida com base em programas fortes ou em ideias absolutas, como as ideias de progresso, de emancipação da humanidade. É isso que aparenta entre si os diversos iluminismos. Essa cultura aqui tem uma potência forte de negatividade. É a cultura da crítica. Essa idealização verdadeiramente teológica da cultura foi marcante no século XIX. Mas quando essa idealização é usada como patrimônio de uma classe social, ela se universaliza, é idealizada e corre o risco de se transformar em uma segunda natureza. A idealização da cultura europeia persistiu até a primeira metade do século passado. Eu cito aqui um texto polêmico de Eliot, que é, em português, "Notas para uma definição da cultura" (Notes toward a definition of culture). É um texto polêmico, em T. S. Eliot, realmente um dos grandes poetas ingleses, em que ele tenta definir um conceito de cultura. Para ele, são três instâncias que definem cultura: o indivíduo, a elite e a sociedade. É isso que estrutura a cultura. São essas três instâncias que se confrontam, que realizam trocas mútuas, mas sempre no interior de uma ordem responsável pela coesão e pelo avanço do todo social. Então, no

Oficina do Historiador, Porto Alegre, EDIPUCRS, v. 8, n. 1, jan./jun. 2015, p. 134-157. 
modelo dele, a cultura pode ser alta ou baixa. Se a elite está ali, é alta; se não está, é baixa. Se ela é alta, é patrimônio de uma minoria, que é uma elite, ou uma casta, e ela pertence a uma classe social que deve ser mantida tal e qual, porque essa classe social é quem recruta e forma a elite responsável pela alta cultura. Essa é a visão de Eliot. A ideia de educação como meio de democratização universal da cultura seria, para Eliot, uma ingenuidade ideológica, porque conduz necessariamente à redução da qualidade.

O que aconteceu com esse tipo de ideia, da qual Eliot é um grande patamar (porque ele é um grande intelectual, grande poeta inglês)? Isso ruiu na pós-modernidade. Isso acabou agora. Isso está ruindo, está desmoronando. De modo geral, hoje, não existem mais modelos definitivos da ideia de cultura. Existem descrições, narrativas de como a cultura se inscreve de modo autorreferente, sem transcendência, na vida social. Você tem hoje alguns sociólogos falando em processos sociais de significação. Ou seja, você diz como é que uma entidade ambígua como cultura se articula com a sociedade. Portanto, como se articula cultura com a produção, com a economia e com o poder. A cultura aí é gerencial. É um elemento fundamental, estruturante, da ideologia de domínio hoje. O que aí não está dito é que, na medida em que essa cultura autorreferente - não mais com referência ao sagrado - se afirma como imprescindível à formação do capital humano, na formação e financeirização do mundo, se verifica uma atração entre essa cultura e o poder de natureza patrimonial que se organiza através da transmissão por grupos específicos. Nota-se hoje uma patrimonialização clara da cultura, mesmo na sociedade brasileira e sobretudo em grupos específicos. Por exemplo, o grupo musical patrimonializa a cultura, entre grupos de amigos, de familiares, em circuitos fechados onde o grupo se patrimonializa e se expande.

Há uma tendência, portanto, à patrimonialização do campo da cultura, que uma pequena burguesia cultural diversificada, uma pequena burguesia cultural que se constituiu e enriqueceu - aliás, ganhou muito dinheiro do início da ditadura militar para cá, dos anos 1960 até agora - uma pequena burguesia cultural diversificada que constitui uma classe cultural que ganhou muito dinheiro, e essa pequena burguesia se caracteriza pela incorporação de um saber fazer em grupos específicos - artistas, esportistas, produtores de evento - e o capital desse grupo é uma linguagem e uma competência técnica. Você não tem mais, portanto, uma grande e única burguesia cultural, mas uma diversidade de grupos patrimoniais, que é a democracia culturalista da mídia, que demarcam os territórios pelas especificidades das suas competências técnico-simbólicas, principalmente na ordem do espetáculo.

Embora se veja aí diferenças em relação às regras do capitalismo industrial puro e 
simples, não há contradições com o jogo da finança e do mercado. Toda essa cultura de entretenimento, de grande ou pequena qualidade, é perfeitamente afim ao jogo financeiro do mercado. Ou seja, a cultura perdeu a potência clássica de negatividade em benefício da integração, pelo entretenimento ou pela informação banalizada. Informação não significa mais nada. A informação pública é pura banalização. E o entretenimento é uma forma de integração social. Quer dizer que ninguém deixa de se divertir; o efeito ideológico dele é esse.

$\mathrm{Na}$ busca de uma perspectiva política, torna-se funcional a concepção de Appadurai eu falo de Arjun Appadurai - para quem cultura não é um substantivo, assim como uma coisa, um objeto. Por exemplo, a minha cultura, a sua cultura, a cultura dos outros. Não é um substantivo. Cultura para Appadurai - e eu acho interessante essa observação - é um adjetivo. Quer dizer, ao invés de dizer 'a cultura', diz 'o cultural'. Quer dizer que nós podemos usar como recurso heurístico para falar das diferenças. A cultura não é uma essência, não é uma transcendência, mas o subconjunto das diferenças que foram selecionadas e foram mobilizadas para articular as fronteiras da diferença. Portanto, ao invés de um sistema de significados, o cultural nos remete ao conflito de significados nas fronteiras dos campos sociais.

Ora, o que eu apresentei aqui? Uma crítica do poder ideológico da noção de cultura. Eu acho que esse poder se esvanece, se esmaece em função da transformação do capitalismo produtivista em financeirização, capital financeirizado, mas também por efeito das novas tecnologias que, de algum modo, impedem a concentração da fala, a concentração da voz em pontos fixos e espalham esses pontos na direção das classes sociais. Agora, se isso é auspicioso do ponto de vista de ativismo, de ação social, é pra gente de classes diferentes, não há mais nenhuma burguesia cultural que se sustente, do ponto de vista ideológico - ideologia entendida aqui não como conteúdo, não como representação doutrinária, mas ideologia entendida como a forma que os conteúdos assumem dentro de um modo de produção - essa disseminação cultural é fortemente ideológica. Ela tem, portanto, uma secreta aliança, um secreto conluio com as novas formas de poder. Obrigado.

Professor, se não me engano, o professor não usou a palavra 'arte', na sua discussão da transição de uma época religiosa a uma época cultural. Como se situa a arte dentro dessa transição simbólica, no âmbito da cultura?

Eu acho que a arte, do mesmo modo que a cultura, talvez seja uma palavra da qual nós

Oficina do Historiador, Porto Alegre, EDIPUCRS, v. 8, n. 1, jan./jun. 2015, p. 134-157. 
devamos nos desembaraçar. Talvez devamos jogá-la fora. Porque a arte se dá tanto na produção quanto no reconhecimento. É arte aquilo que se produz como tal mas que é, também, como tal reconhecido. Ora, esse reconhecimento se dá dentro do quadro daquilo que Walter Benjamin chamou "a aura". Ainda é uma instância do sagrado. Ainda é um fragmento, uma partícula do sagrado para atribuir àquele objeto, àquela produção de natureza simbólica, alguma coisa de único, de singular, alguma coisa, portanto, de real, no sentido em que se defina o real como a singularidade. Quer dizer, o real que se representa mas não esgota totalmente, nunca. O real você pode representá-lo, mas ele não esgota, ele escapa de você como um disco voador, como um objeto não identificado. Essa singularidade que a arte dá se perde com a dessimbolização sagrada do espaço público e da cultura. Então se reproduz, dos grandes movimentos criativos das primeiras décadas do século XX para cá - bom, Hegel já tinha anunciado a morte da arte, nesse sentido - mas o que nós assistimos como produção não quer dizer que essa produção não seja tão importante, não seja significativa - nós assistimos as representações estéticas da morte da arte. É sempre a arte em despedaçamento, é sempre o real, a realidade em despedaçamento, e a própria arte como tal, que nós assistimos morrer e fruímos dessa morte. Fruímos desse luto. Assim é, pelo menos, como eu vejo. Porque, preste atenção, mesmo dos impressionistas para cá, mesmo da arte moderna para cá, quando a subjetividade do artista estava na assinatura - e isso valorizava o quadro, isso valoriza o quadro - era um momento dessa subjetividade singular e única que nós comprávamos. Tanto que você tem em livros de arte que De Chirico, por exemplo, depois da guerra - um grande pintor - foi preso, condenado a um ano - que ele não cumpriu - porque ele falsificou quadros dele. Falsificou depois da guerra quadros da fase azul, que valia mais, quando a fase azul era anterior à guerra. Pintou quadro que ele dizia que era da fase azul e não era mais, porque a fase azul fora anterior. Falsificou a si próprio. Porque a assinatura valia naquele momento. Não estava em questão a qualidade nem a beleza do quadro, era a assinatura de De Chirico.

Quando Picasso fez oitenta anos, eu morava em Paris, e até tentei entrevistá-lo, lá no sul da França, mas ele não recebia ninguém. Eu era jornalista na época. Eu me lembro de ver, no Pétit Palais, quadros de Picasso - Picasso tinha muito quadro - por exemplo, eu vi um que me chamou muito a atenção, e que depois eu vi em outro lugar, na casa de alguém: um quadro, com aniagem, pano de aniagem, pano de limpar chão, da casa dele, que ele pregou com umas tachinhas, ali - e um monstro, um grande artista, realmente, do século XX, genial mas ele fez isso, pregou ali e assinou embaixo: Picasso. Tanto fazia ele botar o pano como

Oficina do Historiador, Porto Alegre, EDIPUCRS, v. 8, n. 1, jan./jun. 2015, p. 134-157. 
não. Se ele assinasse, em um quadro, "Picasso", e eu tivesse um dinheirinho, acho que eu comprava! Porque o que valia mesmo era "Picasso": a assinatura se transferiu para a subjetividade do artista. Essa subjetividade também vai se gastando, mas não se gastou tanto, hoje. Então você tem a obra de galeria, os quadros, e a burguesia ainda compra muito, quadros bonitos, grandes artistas surgem, as pessoas vão visitar aos montes as exposições... Por exemplo, há tempos atrás, em Paris, eu tentei visitar uma exposição do Hopper - que é um pintor que eu gosto muito, Edward Hopper, americano - e não conseguia, porque tinha que ficar horas na fila, debaixo de gelo. Eu desisti, fui ver umas exposições mais fáceis de visitar. E eu gosto de ver exposições. Mas eu tenho plena consciência de que alguma coisa morreu. Alguma coisa morreu. Eu me lembro, eu era muito amigo, amigo pessoal, do Jean Baudrillard, éramos muito amigos, e eu me lembro de uma das últimas vezes em que estava com o Baudrillard conversando sobre um pintor na Holanda que ganha um concurso para fazer uma espécie de instalação. O que ele queria fazer na instalação? Ele conseguiu convencer, com um projeto arquitetônico muito bonito, que ele queria, nos lugares onde a cidade podia apor ainda uma camada de asfalto, ele queria pisar. Ele pisava. Quer dizer, ali ele marcou a paisagem, com o peso dele, de tal e tal forma, com a sola do sapato. Ele ganhou duzentos mil dólares para isso. E era fotografado. Ele então fez isso uns dias, mas depois pensou 'já basta'. A empresa que deu o dinheiro foi com a polícia em cima dele e o obrigaram a botar asfalto e a pisar nas outras, e ele saiu pisando... Isso é o que eu chamo o esvanecimento, a morte. É a subjetividade. A empresa pagou e queria o artista pisando no asfalto. É um artista. Talvez, então, o último gesto da arte que virá - e já está ocorrendo isso será o suicídio do artista. Alguns já estão se matando, com agulhas... O próprio corpo, hoje tem uma arte que atravessa o corpo... Ou seja, é interessante, mas eu diria que é o funeral, que o resto do século XX veio encenando o funeral da arte.

Eu sei que há outras posições e eu não sou nenhum crítico de arte, por isso que eu evitei a palavra arte e falei em produção simbólica. É uma palavra mais fácil, para mim, de caracterizar e de mostrar que há uma atitude de simbolização ali que não carrega a "aura" da grande arte do passado, mas que também não está ali para vender, para ser reduzida pelo valor de uso. É alguma coisa que tem também uma transcendência: mesmo esse pisar no asfalto, tem uma certa transcendência. Mas não é mais uma transcendência na esfera de Deus, como a do passado. É uma transcendência na imanência: é possível, dentro da imanência, ser transcendente. Mas, como há outras formas de transcendência na imanência, eu ficaria com elas. Por exemplo, eu acho que o amor é uma transcendência dentro da imanência. Talvez

Oficina do Historiador, Porto Alegre, EDIPUCRS, v. 8, n. 1, jan./jun. 2015, p. 134-157. 
devêssemos substituir a arte pelo amor.

Professor, muito obrigado pela palestra. A minha questão, acredito, tem relação com sua resposta. O senhor acredita que exista alguma possibilidade de pensar a produção simbólica, ou alguma produção simbólica correlata à chamada arte engajada e, principalmente, se há alguma possibilidade de pensar, ainda, em uma produção simbólica engajada com a televisão? Ou o senhor acredita que já não é mais possível pensar essa relação com a televisão?

Eu acho. Há alguns italianos que fizeram agora essa experiência, várias pessoas que fizeram essa experiência com televisão. Porque aí teríamos que entrar na discussão sobre o que é símbolo. O símbolo não é signo. O símbolo não é palavra. O símbolo é um organizador de trocas. A moeda, por exemplo, é um símbolo. Por quê? Eu tenho uma moeda, aquele real que eu falei aqui - real não, vamos pegar uma moeda mais valorizada, o euro ou a libra... - eu posso, com um euro - com um euro não, com uns vários euros, com uns cinco euros - eu posso, digamos, comprar uma boa cerveja em um boulevard parisiense, eu posso comprar um livro, eu posso comprar um anel, eu posso comprar pão, eu posso comprar um vinho... Eu tenho coisas diferentes - portanto, heterogeneidade - que a moeda vale, por cada um deles. A moeda é, portanto, um organizador geral de trocas. Isso é um símbolo. O símbolo é isso, um organizador de trocas. Não precisa significar nada. Ele é um organizador de trocas. O pai também. A função do pai, o pai é sempre simbólico. Como a moeda se subtrai por valor de uso, o pai também. Alguém é pai de alguém porque não é pai dos outros. Subtrai-se ao consumo. Ele é organizador das funções no interior da família. Portanto, o pai é simbólico. E vai por aí. O falo - tema importante pros lacanianos - o falo também é simbólico. Então vejam só, o símbolo não precisa significar nada. Eu acho que a questão da comunicação, a essência da comunicação, não é a palavra nem o signo. A comunicação pode ser muda. Pode ser muda e ainda assim altamente significativa. Comunicação é uma organização do comum no nível do simbólico. Então, o meu interesse hoje pelas tecnologias, seja a televisão, seja a Internet, é porque estou vendo aí um retorno do simbólico para produção de um novo tipo de comum. Independentemente das finanças, da organização, da ideologia que está ali. É nesse simbólico, nessa dimensão do simbólico - que não é bem a mesma coisa que o imaginário, que é outra coisa - é nessa dimensão do simbólico. A arte sempre atuou na dimensão do simbólico. Sempre. Esses grandes artistas de quem eu falei, ou a poesia - a poesia está aí para 
reduzir tudo que existe a zero e começar de novo. Ou não teria sentido. Seria poesia de quem? A poesia plena de significado, de sentido, só da rima, não diz muito. Eu acho que é possível, nesse nível da dimensão do simbólico, que é um nível de organização fundamental, básica, com os materiais que estão aí, seja a televisão, seja até o celular, seja que material for, é, digamos, retomar ou produzir simbolicamente. Eu acho que é possível. E que, talvez, essas tentativas, nas quais eu fui, talvez, irônico demais aqui, da instalação - algumas, muito interessantes - podem ser, às vezes, mesmo nesse nível. Mas eu acho, de qualquer modo, que o artista deveria se dissolver um pouco na paisagem, e guardar o sorriso. Descobrir o sorriso. Deixar de ter esse pedantismo da aura e abrir-se pro sorriso, rir de si mesmo um pouco. Talvez o simbólico venha junto com o riso.

Aquela frase que eu citei há pouco, do Lawrence Durrell: até os 18 anos, eu me considerava um gênio, mas aí eu descobri o sorriso. [risos] Então já não se considerava mais. Tem que descobrir o sorriso. Eu acho que essas produções do simbólico são possíveis, sim, na televisão. Eu espero ver, eu quero ver. Talvez estejam se dando por aí e eu não saiba. Como eu disse, eu não sou crítico de arte.

Eu espero que eu tenha claro e que não tenha chateado ninguém, porque um dos pecados mortais para mim é ser chato. Por exemplo, eu sou leitor obrigatório de Aristóteles, mas eu acho Aristóteles meio chato. E Platão não é chato.

Professor, já que você falou de Aristóteles e de Platão, e como no início você tinha falado da boa retórica e da má retórica, eu pergunto: tem espaço, hoje em dia, para a boa retórica na mídia de um modo geral? Onde? Internet? Espaço que não seja excepcional, motivado por iniciativas individuais, mas sim por algo mais consistente.

A Internet ainda não descobriu a retórica realmente. Gozado, a mídia jurássica, tradicional, viveu da má retórica, dessa mesma retórica, com espaços para a retórica do diálogo, que eu acho que está um pouco nesses nichos jornalísticos que se diz jornalismo de qualidade: o Le Monde Diplomatique... Mas até isso tem o seu público reduzido. E o compromisso da retórica é, também, a compreensão, com a disseminação e ampliação do público. Eu acho que isso virá, de algum modo, desse diálogo instituído pela internet. Eu acho que virá daí a boa retórica. Agora, é preciso também, à luz disso que eu trouxe para vocês, reinterpretar o que quer dizer diálogo. Porque nós entendemos diálogo como fala e conversa. Essa é a origem da palavra grega: légein e dia. Então, se conversa, se fala, se dialoga, e aí se 
dá uma preeminência muito grande ao que é dito, à fala. Mas há outra maneira de entender diálogo e, portanto, entender a retórica. Esse légein também quer dizer cavar. Esse dia é através do vazio. Esse cavar através do vazio, às vezes, é quebrar as barreiras onde a fala se dá tranquilamente, a fala da conciliação. Às vezes as pessoas conversam educadamente, conversam logicamente, mas não realmente dialogando. É diálogo de surdos, exibição. Às vezes, quebrar uma barreira é dialogar, é cavar através do vazio.

Então, por exemplo: eu não tenho nenhuma certeza grande em relação a essas manifestações. ${ }^{1}$ Em princípio, eu acho legal. Mas eu diria que não é diálogo que estão buscando. O governo diz 'vamos dialogar'. Mas o jovem é, às vezes, como o povo, que sabe, mas não sabe que sabe. Não é diálogo no sentido de conversa a dois. É diálogo no sentido de quebrar barreiras. Então eu acho que eu, hesitanto, digo que talvez, nesse ronco das ruas, haja um quebrar de barreiras. E por que exatamente nas ruas? Porque dizem 'nós saímos do facebook'. Saímos da mídia. Eu não acho. Eu acho que a mídia é um meio de mobilização, um grande megafone. Eles saíram mesmo de outro lugar. Foi a rua que produziu essa gente.

Porque, veja só, sabem o que quer dizer rua, realmente? Tem um latinista aqui. Eu fui latinista, mas professor de latim de província de Bahia. Mas lá tinha uma língua que eu gosto. A palavra rua vem de ruga. Em latim é ruga, e isso deu rua. Em inglês é street, não tem nada a ver com ruga. Em alemão é Straße. Mas veio também do latim, porque via é estrada, caminho pavimentado, que deu street, deu Straße etc. Eu acho que é a rugosidade da paisagem que esse pessoal está representando. Quer dizer, ser ruga ali onde o espaço quer ser liso. Porque esse diálogo muito culto, muito educado, é a linguagem também da embromação. E da dominação. De repente você quebra a barreira. É um outro tipo de diálogo.

Então a retórica pode ser dar também sem palavras. Barthes mostrou isso magnificamente em Fragmentos de um discurso amoroso, quando ele disse 'olha, a frase eu te amo não significa nada'. Realmente, se duas pessoas dizem, uma para a outra, "eu te amo", e já têm uma relação, por que dizer? Evidentemente, é tautológico, tautologia pura. Ele quer dizer 'quando você diz eu te amo, você quer dizer outra coisa'. Talvez 'eu quero te seduzir', ou 'eu te seduzo'. Essa fórmula, em si mesma, é vazia. Mas é forte. Tem um poder. Mas quando você, digamos, derruba a fórmula, como pode derrubar na rua, você descobre o corpo em outra direção. Então, eu não vejo comunicação e não dou importância ao próprio jornalismo, como os jornalistas estavam falando, os mais velhos, o pessoal da Mídia Ninja no Roda Viva: 'não são objetivos'. Nenhum jornalista foi objetivo. Ninguém foi objetivo. A mídia, a imprensa

1 Referência às diversas mobilizações de rua ocorridas em várias capitais do país em meados de 2013.

Oficina do Historiador, Porto Alegre, EDIPUCRS, v. 8, n. 1, jan./jun. 2015, p. 134-157. 
brasileira, não foi objetiva durante a ditadura, com raras exceções. Mentia, calava. Essa objetividade também é muito conveniente. Então, não é reportar objetivamente fatos - isso que o Dewey disse, 'olha, é conectar as pessoas, para que, uma vez no espaço público, as palavras possam ter um sentido além do convencional que elas têm'. Aí, essa outra retórica, a boa retórica de hoje, a retórica platônica, talvez não se faça apenas com palavras. E nesse sentido a nova mídia pode ser importante.

O senhor falou algo que é quase senso comum, que a mídia atual trabalha com uma ideia de produção de conteúdo. Só que, se nós observarmos, o que se apresenta, na verdade, é uma quase mimetização estética, geral, em diversos meios. A minha pergunta é se não seria na verdade uma mídia produtora de forma, muito mais que de conteúdo, até pelo que o senhor acabou de falar. Então, lidar não tanto com palavras, mas sim com imagens, nesse sentido. Se nós pensarmos de um ponto de vista tecnológico, na ideia de direitos sociais e tudo mais, cada vez mais, essa hipervalorização da forma, do estético. Algo bem pósmoderno.

Você acabou de resumir, e resumiu muito bem - resumiu não, você expandiu - a fórmula resumida de Marshall McLuhan: "o meio é a mensagem”. Claro que é. Quando eu disse aqui 'olha, a ideologia não é o conteúdo, ideologia é a forma que os conteúdos assumem socialmente'. A forma de poder que assumem. A forma hoje é midiática. É essa mídia. O compromisso excessivo com a forma faz com que ela também se perca nas imagens sobre si mesma. E o que a mídia fala mais é de si mesma, é de seu próprio poder. A mídia é - eu ia dizer 'uma mulher vaidosa', já ia entrar no politicamente incorreto - é uma pessoa muito vaidosa, falando sempre de si mesma. Eu estava dando palestra há um tempo atrás para uns professores americanos, queriam que eu falasse em inglês sobre o Brasil, e eu disse 'o homem brasileiro é uma pessoa irmã etc.'. E disseram 'como o homem brasileiro? E a mulher brasileira?'. Eu disse 'não, é brazilian man', e me responderam 'não, diga brazilian person'. Pessoa brasileira. Então, a mídia na verdade é isso, fala muito de si mesma. E de seu próprio poder. A mídia é uma forma. Os conteúdos são, cada vez mais, importantes. Por isso que hoje, era breve a conversa - era você que estava lá? Ah, sim; é o menino da Mídia Ninja que está aí - ele disse 'nós damos novos ângulos'. Claro que dão novos ângulos, mas pra mim não é o importante. Pra mim, o importante é que novas vozes, essa pluralidade de vozes, se levantam e digam o que disserem. Digam o que disserem, é a pluralidade de vozes que faz uma conexão 
diferente. Porque esse primado do conteúdo é o primado do velho jornalismo. E nisso eles seriam, talvez, insuperáveis. Porque paga bem, tem intelectuais: se você lê o Le Monde Diplomatique, é difícil você distinguir, saber qual é o discurso das Ciências Sociais e o discurso do Le Monde Diplomatique. O discurso da Sociologia, hoje, está muito próximo do discurso desse jornalismo de qualidade. E é muito agradável ler aqueles bons artigos. Mas aquilo vai reduzindo seu público. E quando vai reduzindo seu público, você reencontra Dewey dizendo assim: 'você tem que ter uma boa retórica e ampliar o público'. Só que essa nova boa retórica para ampliação do público talvez não dependa mais de palavras, mas dependa de muitas outras coisas além de palavras. Dependa de ações. Dependa de danças. Quem é daqui que conhece bem a Bíblia? Lembram quando Davi recebe a arca? Ele não diz nada diante da arca, ele simplesmente dança diante da arca. Ele dança diante da arca. É um episódio célebre de Comunicação, dentro da Bíblia. Muito ensinado. Só dançou. Às vezes é isso: dançar, quebrar uma coisinha, tudo isso pode ser comunicação.

A ideia da técnica digital, segundo a qual ela ampliou, despolitizou também, deseducacionalizou a massa. E há ideias que nós vínhamos aprendendo, agora que precisamos de reajustá-las. Essa técnica digital, meio de comunicação, hoje em dia, seria mais ou menos um quarto poder, que o Estado ou um governo pode ter, para controlar, educar as massas. Mas a abordagem do professor pareceu-me distanciar-se desta visão da qual nós nos orgulhamos no Brasil, na África e em outras partes do mundo: organizarmos, educarmos a partir do facebook, organizar manifestações etc. como um poder. Mas o professor diz que é um poder que já está fora do controle da própria autoridade governamental, do próprio Estado. Eu gostaria de ouvir mais um comentário sobre se é possível continuarmos a afirmar isso, a sustentar a ideia de que é um quarto poder de fato, as tecnologias de comunicação e informação, ou se já deixou, de fato, de ser, olhando para as manifestações que são organizadas.

A ideia do quarto poder é uma ideia antiga e que decorre da maneira como o Estado se organiza. Além dos poderes constitucionais, bota a imprensa como quarto. Eu não acho que seja isso. Eu acho que talvez fosse o caso de ler Foucault, que tem outra ideia de poder. Poder como táticas múltiplas, como dispositivos que se enraízam nas relações, e não centrados, unidirecionais. Não é poder como a força que move ou que controla, que é a ideia de poder de Estado. Você é de que país africano?

Oficina do Historiador, Porto Alegre, EDIPUCRS, v. 8, n. 1, jan./jun. 2015, p. 134-157. 
Eu sou de Moçambique.

Há duas palavras, nos cultos da Bahia, aos quais eu pertenço. Em nagô você tem duas palavras para dizer poder, para dizer poder-força. Em iorubá, você pode dizer agbará, que é força física, como eu empurro isto aqui [empurrando a garrafa de água]. Isso é puro agbará. Alguém me empurra, eu empurro de volta. Isso é agbará. Daí Exú-bará, Exú-agbará, porque é a força que empurra. Mas você tem um outro tipo de força, de poder, que não é a força contra, a que empurra. É a força pró. Isso se chama, em iorubá, axé. Axé quer dizer isso, axé é força pró. A informação é mais força pró do que força contra. Enquanto o Estado ainda está dentro da lógica da força contra, força de controle físico, de exercício físico. O fortalecer-se é da ordem do axé. O poder informacional é um poder que se abre para o fortalecimento próprio. Portanto, ele não pode estar concentrado, como um quarto poder. Ele está em todos os lugares. Como essa figura que eu falei há pouco, que é Exú. Está em tudo. Está em todos os lugares. Isso é axé, isso é força pró. Portanto, teríamos que rever a ideia de poder, a noção de poder, para então poder entender essa questão. Mas não vejo, portanto, como quarto poder, não.

\section{REFERÊNCIAS}

ELIOT, T. S. Notas para uma definição de cultura. Trad. Geraldo Gerson de Souza. São Paulo: Perspectiva, 2013. (Debates; 215).

SODRÉ, Muniz. Antropológica do espelho: uma teoria da comunicação linear e em rede. Petrópolis/RJ: Vozes, 2002.

SODRÉ, Muniz. As estratégias sensíveis: afeto, mídia e política. Petrópolis/RJ: Vozes, 2006. 